\title{
Efektivitas Sanksi Pajak Kendaraan Bermotor terhadap Kepatuhan Wajib Pajak Orang Pribadi dengan Tingkat Penghasilan Wajib Pajak Sebagai Variabel Pemoderasi di Kabupaten Buleleng
}

\author{
Mahendra $^{1 *}$, Nyoman Ari Suryadharmawan ${ }^{2}$ \\ ${ }^{123}$ Akuntansi, Universitas Pendidikan Ganesha, Buleleng \\ *made.ardi.mahendra@undiksha.ac.idl*
}

\section{Abstrak}

Untuk dapat memperoleh pendapatan yang maksimal dari Pajak Kendaraan Bermotor, diperlukan adanya kepatuhan dari wajib pajak itu sendiri. Tingkat kepatuhan wajib pajak dapat dipengaruhi oleh adanya sanksi pajak sebagai upaya preventif untuk menertibkan dan membuat jera wajib pajak dan pelanggar pajak. Namun, sanksi pajak yang sudah terakumulasi cukup besar seringkali membuat masyarakat yang memiliki tingkat penghasilan yang terbatas untuk tidak membayarkan kewajibannya.Untuk itu, penelitian ini bertujuan untuk menginvestigasi efektivitas sanksi pajak terhadap kepatuhan wajib pajak dengan tingkat penghasilan wajib pajak sebagai variabel pemoderasi. Penelitian ini merupakan penelitian kuantitatif dengan metode analisis regresi linear berganda dengan 100 wajib pajak orang pribadi sebagai sampel penelitian. Data dikumpulkan dengan menggunakan kuesioner pertanyaan tertutup dengan skala Likert. Hasil penelitian menunjukkan bahwa sanksi pajak kendaraan bermotor memberikan efektivitas sebesar 12,4\% terhadap kepatuhan wajib pajak sedangkan tingkat penghasilan wajib pajak bukan merupakan variabel pemoderasi yang mempengaruhi hubungan antara sanksi pajak dengan kepatuhan wajib pajak.

Kata Kunci : Pajak Kendaraan Bermotor, Efektivitas, Sanksi Pajak, Kepatuhan Wajib Pajak, Tingkat Penghasilan

\section{Abstract}

In order to get the maximum income from Motor Vehicle Tax, it is necessary to have compliance from the taxpayer itself. The level of taxpayer compliance can be affected by the existence of tax sanctions as a preventive effort to curb and deter taxpayers and tax offenders. However, large accumulated tax sanctions often make people with limited income not paying their obligations. Therefore, this study aimed to investigate the effectiveness of tax sanctions on taxpayer compliance with taxpayer income levels as a moderating variable. This research was a quantitative study which used multiple linear regression analysis method with 100 individual taxpayers as the sample. The data were collected using a closed-ended questionnaire with Likert scale. The results show that motor vehicle tax sanctions provide $12.4 \%$ effectiveness on taxpayer compliance, while the income level of taxpayers is not a moderating variable that affects the relationship between tax sanctions and taxpayer compliance.

Keywords: Motor Vehicle Tax, Effectiveness, Tax Sanctions, Taxpayer Compliance, Income Levels

\section{Pendahuluan}

Negara membutuhkan dana yang besar dalam menjalankan dan memenuhi segala kebutuhan pemerintahanan dan pembangunannya (Winerungan, 2013). Untuk itu, negara melakukan pungutan pajak guna meningkatkan penerimaan negara. Pajak merupakan pungutan yang dibebankan kepada masyarakat yang bersifat memaksa dan terutang yang kemudian digunakan untuk kebutuhan negara dengan berdasarkan pada ketentuan UU

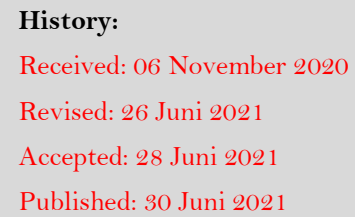

Publisher: Undiksha Press

Licensed: This work is licensed under

a Creative Commons Attribution 3.0 License

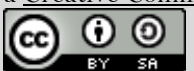


(Siahaan, 2004). Namun dalam pelaksanaannya, pemerintah pusat bukan merupakan satusatunya pihak yang berhak untuk melakukan pemungutan pajak. Hal ini dikarenakan berdasarkan pada asas otonomi daerah seperti yang tertuang dalam UU No. 32 Tahun 2004 tentang Pemerintahan Daerah dan UU No. 33 Tahun 2004 tentang Perimbangan Keuangan antara Pemerintah Pusat dan Pemerintahan Daerah, pemerintah pusat memberikan kewenangan yang seluas-luasnya disertai dengan pemberian hak dan kewajiban menyelenggarakan otonomi daerah dalam kesatuan sistem penyelenggaraan pemerintahan. Aturan ini memberikan kewenangan bagi pemerintah daerah untuk memungut pajak daerah dan retribusi daerah untuk meningatkan penerimaan pendapatan asli daerah.

Ketentuan mengenai pajak daerah kemudian diatur lebih lanjut dalam UU No. 28 Tahun 2009 tentang Pajak dan Retribusi Daerah yang kemudian diatur lebih lanjut oleh daerah masing-masing dalam Peraturan Daerah (Perda) maupun Peraturan Gubernur (Pergub). Terdapat beberapa jenis pajak yang dapat dipungut oleh daerah, salah satunya adalah Pajak Kendaraan Bermotor (PKB). Di Provinsi Bali sendiri, ketentuan mengenai pungutan terhadap PKB diatur dalam Perda Provinsi Bali No. 1 Tahun 2011 tentang Pajak Daerah. Disebutkan bahwa PKB merupakan pajak yang dipungut dari wajib pajak atas kepemilikan dan/atau penguasaan kendaraan bermotor. Adapun lembaga yang berwenang dalam mengurus PKB adalah Badan Pendapatan Daerah melalui Kantor Bersama Sistem Administrasi Manunggal di Bawah Satu Atap (SAMSAT). Karena PKB merupakan pungutan pajak yang dibebankan pada objek kendaraan bermotor, maka meningkatnya jumlah kendaraan bermotor diharapkan dapat pula meningkatkan jumlah penerimaan pajak kendaraan bermotor (Widnyani \& Suardana, 2016). Pada kenyataannya, jumlah kepemilikan kendaraan bermotor di Indonesia terus mengalami peningkatan setiap tahunnya.

Menimbang banyaknya kendaraan bermotor setiap tahunnya, tentunya penerimaan pemerintah yang berasal dari pajak kendaraan bermotor juga mengalami peningkatan yang kemudian dapat digunakan untuk pembangunan daerah. Provinsi Bali merupakan salah satu provinsi yang diperkenankan mengelola pajak daerah sebagai sumber pendapatannya dan PKB merupakan salah satu sumber perolehan pajak terbesar yang ada di Provinsi Bali. Pada tahun 2019 saja, Provinsi Bali memeroleh pendapatan sebesar Rp.1.560.964.729.126 dari PKB (Badan Pendapatan Daerah Provinsi Bali, 2019). Sebagai salah satu dari 8 kabupaten dan 1 kota di Provinsi Bali, Kabupaten Buleleng merupakan salah satu yang memberikan pendapatan yang signifikan terhadap perolehan pajak daerah di Provinsi Bali dari sector PKB. Kabupaten Buleleng mampu menyumbang PKB sebesar hampir Rp. 1,5 miliar terhadap realisasi penerimaan PKB Provinsi Bali, yang mencapai total Rp. 1.5 triliun (Wijaya/BaliPost, 2020).

Perolehan PKB yang besar di Kabupaten Bulelengdisebabkan oleh jumlah kendaraan bermotor di Kabupaten Buleleng yang terus mengalami peningkatan. Berdasarkan data yang dirilis oleh Kantor SAMSAT Buleleng (2020), pada tahun 2019 terdapat total 349.996 kendaraan bermotor di Kabupaten Buleleng. Jumlah ini mengalami peningkatan yang cukup signifikan dari tahun-tahun sebelumnya. Hal ini menunjukkan bahwa jumlah kendaraan bermotor di Kabupaten Buleleng dapat meningat sangat pesat dalam rentang waktu satu tahun saja. Detail dari jumlah peningkatan kepemilikan kendaraan bermotor di Kabupaten Buleleng dapat dilihat pada Tabel 1. 
Tabel 1. Jumlah Objek PKB yang Sudah dan Belum Membayarkan PKB pada 2017-2019

\begin{tabular}{ccccc}
\hline No. & Tahun & Total Objek PKB & $\begin{array}{c}\text { Unit yang Sudah } \\
\text { Membayar }\end{array}$ & $\begin{array}{c}\text { Unit yang Belum } \\
\text { Membayar }\end{array}$ \\
\hline 1 & 2019 & 298.871 & 247.746 & 51.125 \\
\hline 2 & 2018 & 282.513 & 234.822 & 47.691 \\
\hline 3 & 2017 & 267.958 & 221.724 & 46.234 \\
\hline
\end{tabular}

Sumber: Kantor SAMSAT Buleleng, 2020

Berdasarkan Tabel 1, dapat dilihat bahwa terjadi peningkatan jumlah kendaraan bermotor setiap tahunnya di Kabupaten Buleleng. Namun demikian, jumlah objek pajak yang tidak membayarkan kewajiban pajaknya juga mengalami peningkatan setiap tahunnya terlepas dari jumlah kepemilikan kendaraan bermotor yang semakin meningkat setiap tahunnya. Hal ini menunjukkan, terlepas dari tingkat konsumsi masyarakat yang meningkat, yang ditunjukkan dengan bertambahnya jumlah objek PKB, masyarakat masih memiliki kesadaran yang cukup rendah untuk membayarkan kewajibannya.

Untuk dapat memperoleh pendapatan yang maksimal dari sektor PKB, maka diperlukan adanya kepatuhan dari wajib pajak itu sendiri. Riahi (2004) menyampaikan bahwa kepatuhan yang tinggi dari wajib pajak merupakan faktor penting dalam pelaksanaan sistem pemungutan pajak yang efektif. Semakin tinggi tingkat kepatuhan wajib pajak maka pelaksanaan kewajiban perpajakan semakin baik dan target pencapaian PKB dapat terwujud (Muliari, 2011). Apabila kepatuhan masyarakat dalam membayar pajak masih rendah maka akan menyebabkan banyaknya potensi pajak yang tidak dapat dimanfaatkan.

Menurut hasil observasi awal melalui wawancara dengan Bapak I Gusti Ngurah Darmika, Kasi Pelayanan PKB dan BBNKB di Kantor SAMSAT Buleleng, pemerintah menerapkan sanksi yang mengatur secara tegas mengenai konsekuensi keterlambatan pembayaran pajak sebagai langkah penggalakan penerimaan pajak. Sanksi ini merupakan upaya preventif agar peraturan perpajakan yang telah diatur dapat dipatuhi dan tidak dilanggar serta dapat memberikan efek jera bagi pelanggar (Nurlaela, 2018). Keberadaan sanksi pajak menjadi penting karena wajib pajak akan memenuhi kewajibannya apabila sanksi dipandang akan lebih banyak merugikan wajib pajak (Nugroho, 2006). Besarnya pengaruh sanksi pajak terhadap kepatuhan wajib pajak tercermin dalam penelitian yang dilakukan oleh Ummah (2015), Dewi, dkk., (2017), Silalahi (2017), dan Widyana dan Putra (2019) yang menyatakan bahwa keberadaan sanksi atau denda pajak memberikan pengaruh yang signifikan dalam meningkatkan kepatuhan Wajib Pajak dalam membayarkan kewajibannya.

Penerapan sanksi PKB didasarkan pada Perda Provinsi Bali No. 1 Tahun 2011 yang menyatakan dalam pasal 12 ayat (3) bahwa Wajib Pajak PKB yang terlambat membayarkan kewajibannya akan dikenakan sanksi administrasi sebesar 25\% (dua puluh lima persen) dari pokok pajak. Jumlah sanksi ini kemudian dikalikan dengan waktu keterlambatan. Keterlambatan pembayaran, meski hanya satu hari, tetap dihitung sebagai keterlambatan satu bulan. Selain itu, pengendara yang belum melakukan pembayaran PKB saat terjaring razia juga akan menerima tilang. Data dari kantor SAMSAT Buleleng menunjukkan bahwa peran sanksi pajak dalam total penerimaan wajib pajak tergolong cukup besar karena menyumbang hingga 3-4\% dari total penerimaan PKB Kabupaten Buleleng.

Meskipun keberadaan sanksi pajak dinilai sangat signifikan, pada tahun 2019, Gubernur Bali mengeluarkan Pergub Provinsi Bali No. 28 Tahun 2019 tentang Pengurangan atau Penghapusan Sanksi Administrasi berupa Bunga dan Denda terhadap Pajak Kendaraan Bermotor dan Bea Balik Nama Kendaraan Bermotor yang diberlakukan dari tanggal 5 Agustus 2019 hingga 6 Desember 2019. Pergub ini menghapuskan sansi administrasi terhadap wajib pajak yang terlambat membayarkan kewajibannya sehingga, wajib pajak 
hanya perlu membayarkan pajak pokoknya saja. Penghapusan sanksi pajak ini dikenal dengan istilah pemutihan.Dikutip dari Mardiastuti/detik.com (2019), Sekretaris Daerah Provinsi Bali, Dewa Indra, menyatakan bahwa penerapan pergub ini didasari pada pemikiran bahwa apabila pemutihan tidak dilakukan, maka denda yang sudah terlanjur terakumulasi cukup besar akan membuat orang semakin tidak ingin membayarkannya, utamanya orang dengan penghasilan yang pas-pasan.

Fenomena penunggakan pajak ini memiliki keterkaitan yang erat dengan kondisi keuangan wajib pajak itu sendiri. Torgler (2003) menyatakan bahwa seseorang yang mengalami kesulitan keuangan akan merasa tertekan ketika mereka diharuskan membayar kewajibannya termasuk pajak. Lebih lanjut, Bloomquist (2003) mengidentifikasi bahwa tuntutan keuangan merupakan salah satu sumber tekanan bagi wajib pajak dengan pendapatan yang terbatas. Hal ini kemudian berujung pada terjadinya penghindaran pembayaran pajak dikarenakan dengan jumlah penghasilan yang terbatas, wajib pajak harus tetap membiayai kebutuhan keluarganya, dimana seringkali jumlah pengeluarannya lebih besar dari pendapatannya. Tingkat penghasilan dari wajib pajak dapat dilihat memberikan pengaruh yang cukup signifikan, entah dalam meningkatkan atau pun menurunkan kepatuhan wajib pajak dalam membayarkan kewajibannya.

Berdasarkan pembahasan di atas, maka dapat dilihat bahwa efektivitas dari penerapan sanksi pajak terhadap kepatuhan wajib pajak dapat dipengaruhi, baik secara positif maupun negatif oleh tingkat penghasilan wajib pajak itu sendiri. Pembahasan tersebut menyatakan bahwa seseorang yang memiliki penghasilan terbatas akan mengalami kesulitan dalam membayarkan kewajiban pajaknya. Oleh sebab itu, wajib pajak dengan tingkat penghasilan yang baik sepatutnya memiliki kepatuhan yang lebih tinggi untu membayarkan kewajibannya. Namun, berdasarkan hasil observasi awal yang dilakukan di kantor SAMSAT Buleleng, tidak terdapat data yang valid yang menunjukkan bahwa wajib pajak dengan penghasilan tinggi memiliki kepatuhan pajak yang tinggi sehingga tidak perlu sampai membayar sanksi pajak.

Untuk itu, penelitian ini bertujuan untuk menginvestigasi lebih jauh mengenai efektivitas sanksi pajak kendaraan bermotor terhadap kepatuhan wajib pajak orang pribadi di Kabupaten Buleleng dengan menjadikan tingkat penghasilan wajib pajak sebagai variabel pemoderasi, dimana wajib pajak yang nantinya akan dijadikan sampel merupakan wajib pajak dengan tingkat penghasilan yang tinggi. Adapun Kabupaten Buleleng dipilih sebagai setting dalam penelitian ini karena pertimbangan jarak dan waktu, serta pelaksanaan pemungutan pajak yang sudah efektif dan melampaui target.

Berbeda dengan penelitian sebelumnya yang dilakukan oleh Ummah (2015), Dewi, dkk., (2017), Silalahi (2017), dan Widyana dan Putra (2019) yang meneliti mengenai pengaruh sanksi atau denda pajak terhadap kepatuhan Wajib Pajak dalam membayarkan kewajibannya, penelitian ini menawarkan hal yang baru dengan meneliti bukan hanya pengaruh dari sanksi pajak terhadap kepatuhan wajib pajak kendaraan bermotor, namun juga pengaruh dari tingkat penghasilan wajib pajak yang berperan sebagai variabel pemoderasi. Untuk itu, penelitian ini memberikan novelty dari segi variabel penelitian.

Penelitian ini penting untuk dilakukan mengingat perlunya dilakukan kajian yang lebih dalam mengenai efektivitas sanksi pajak terhadap kepatuhan Wajib Pajak kendaraan bermotor. Hal ini karena sanksi pajak yang efektif tentunya dapat meningkatkan kepatuhan Wajib Pajak dan berimbas pada penerimaan pajak daerah yang lebih maksimal. Terkait dengan penggunaan tingkat penghasilan Wajib Pajak sebagai variable pemoderasi, hal ini didasarkan pada teori yang disampaikan oleh Torgler (2003) dan Bloomqist (2003) dimana tingkat penghasilan seseorang dapat berpengaruh terhadap kepatuhannya dalam membayarkan kewajiban pajaknya. Kemudian, keberadaan pemutihan pajak juga menjadi hal 
yang mendasari penggunaan variable pemoderasi ini. Apabila kemudian sanksi pajak saja sudah efektif, mengapa kemudian pemutihan dilakukan untuk mendorong Wajib Pajak dengan denda tinggi namun penghasilan rendah untuk membayarkan kewajibannya. Untuk itu penelitian ini bertujuan untuk (1) efektivitas sanksi pajak kendaraan bermotor terhadap kepatuhan wajib pajak orang pribadi di Kabupaten Buleleng serta (2) moderasi tingkat penghasilan wajib pajak orang pribadi terhadap hubungan antara efektivitas sanksi pajak kendaraan bermotor dengan kepatuhan wajib pajak orang pribadi di Kabupaten Buleleng.

\section{Metode}

Penelitian ini merupakan penelitian kuantitatif. Penelitian kuantitatif didefinisikan sebagai suatu proses menginvestigasi pengetahuan dengan data berupa angka (Kasiram, 2008). Adapun tujuan dipilihnya jenis penelitian ini adalah untuk menguji dan menganalisis efektivitas sanksi pajak terhadap kepatuhan wajib pajak kendaraan bermotor di Kabupaten Buleleng. Metode yang digunakan adalah analisis linier berganda. Jenis penelitian ini dipilih karena disesuaikan dengan tujuan penelitian ini yaitu untuk mengetahui efektivitas variabel bebas sanksi pajak terhadap variabel terkait kepatuhan wajib pajak kendaraan bermotor di Kabupaten Buleleng.

Populasi dalam penelitian ini adalah seluruh wajib pajak kendaraan bermotor di kantor SAMSAT Buleleng di tahun 2019 sebanyak 298.871 orang. Kemudian, sampel dipilih dengan menggunakan tekniksimple random samplingdimana pengambilan sampel dilakukansecara acak tanpa memerhatikan unsur tertentu yang ada dalam populasi itu.Untuk menentukan besarnya sampel, peneliti menggunakan rumus dengan Metode Slovin. Adapun rumus dari Metode Slovin adalah sebagai berikut:

$$
\frac{\mathrm{N}}{\mathrm{N} . \mathrm{d} 2+1}
$$

$$
\begin{aligned}
& \text { Dimana: } \\
& \mathrm{n}=\text { ukuran sampel } \\
& \mathrm{N}=\text { ukuran populasi } \\
& \mathrm{d}=\text { batas toleransi kesalahan }
\end{aligned}
$$

Menurut Umar (dalam Setiawan, 2007), nilai batas toleransi kesalahan (d) pada metode Slovin didasarkan atas pertimbangan peneliti. Slovin masih memberi kebebasan untuk menentukan nilai batas kesalahan atau error level. Penelitian ini menggunakan batas toleransi kesalahan sebesar $10 \%$. Dengan demikian, maka jumlah sampel dari penelitian ini adalah sebanyak 100 orang, pembulatan yang didapatkan dari hasil perhitungan dengan rumus Slovin yang menghasilkan angka sejumlah 99,966552.

Penelitian ini menggunakan metodefield research atau penelitian lapangan. Data primer diperoleh melalui field research atau penelitian lapangan untuk mengumpulkan data secara lengkap dengan menggunakan metode angket/kuesioner. Data primer bersumber dari wajib pajak orang pribadi yang terdaftar di kantor SAMSAT Buleleng, dimana data tersebut diperoleh melalui penyebaran kuesioner kepada tiap-tiap sampel.Instrumen yang digunakan untuk pengumpulan data dalam penelitian ini adalah kuesioner. Adapun bentuk kuesioner yang digunakan adalah bentuk pertanyaan tertutup, responden tidak diberikan kesempatan untuk menjawab selain jawaban yang tersedia pada kuesioner. Kuesioner yang dipergunakan dalam penelitian ini merupakan kuesioner dari penelitian sebelumnya yang dilakukan oleh Khoiroh (2017) yang memiliki variabel yang mirip dengan variabel dalam penelitian ini.

Kuesioner yang sudah disebarkan ke responden kemudian dilakukan pengujian validitas agar data yang didapat menjadi lebih valid sehingga siap diujikan ke sampel 
penelitian. Kuesioner dapat didefinisikan sebagai suatu alat pengumpulan informasi dengan sejumlah pertanyaan tertulis untuk kemudian dijawab secara tertulis juga oleh responden (Sugiyono, 2014). Daftar pertanyaan yang diajukan oleh peneliti bersifat tertutup, dimana alternatif jawaban telah ditentukan sebelumnya oleh peneliti. Jawaban atas pertanyaanpertanyaan dalam kuesioner ini telah dirumuskan sebelumnya dengan lima pilihan yaitu: Sangat setuju, Setuju, Ragu, Tidak setuju, dan Sangat tidak setuju. Pemberian skor terhadap nilai kuesioner dilakukan peneliti dengan menggunakan ketentuan skala Likert sebagai berikut:

1) Jawaban sangat setuju diberi skor 5

2) Jawaban setuju diberi skor 4

3) Jawaban ragu diberi skor 3

4) Jawaban tidak setuju diberi skor 2

5) Jawaban sangat tidak setuju diberi skor 1

Data kemudian dianalisis menggunakan teknik analisis statistik deskriptif, uji kualitas data yang terdiri dari uji validitas dan uji reliabilitas. Uji asumsi klasik terdiri dari uji normalitas, uji multikolinieritas, dan uji heterokesdatisitas. Untuk uji hipotesisdigunakan uji regresi linier berganda, uji koefisien determinasi (Adjust $R^{2}$ ), uji parsial (uji T) dan uji Moderated Regresion Analysis (MRA).

Analisis statistik deskriptif adalah analisis statistik yang digunakan untuk menganalisis data dengan cara mendeskripsikan atau menggambarkan data yang telah terkumpul sebagaimana adanya tanpa bermaksud membuat kesimpulan yang berlaku untuk umum atau generalisasi (Sugiyono, 2014). Lebih lanjut lagi, analisis ini berfungsi untuk memberikan gambaran atau deskripsi suatu data yang dilihat dari rata-rata (mean) dan standar deviasi.

Sugiyono (2014) menyatakan bahwa uji validitas dilakukan untuk memvalidasi instrumen yang digunakan, sehingga instrumen tersebut dapat digunakan untuk mengukur apa yang seharusnya diukur. Dalam penelitian ini, kuesioner merupakan instrumen yang digunakan. Pengukuran mengenai valid atau tidaknya kuesioner dengan dilihat dengan menggunakan Pearson Correlation yang kemudian dibandingkan dengan harga $r_{\text {tabel. }}$ Candiasa (2011) menyatakan jika nilai Pearson Corelation lebih dari $\mathrm{r}_{\text {tabel }}$ maka terdapat korelasi yang signifikan antara skor butir dengan skor total yang artinya butir bersangkutan dinyatakan valid.

Uji reliabilitas dilakukan untuk memastikan bahwa informasi yang ada pada indikator dalam kuesioner tidak berubah-ubah atau konsisten. Uji reliabilitas dilakukan untuk menguji apakah jawaban dari responden konsisten atau stabil. Ghozali (2011) menyatakan bahwa suatu variabel dikatakan reliable jika memberikan nilai Cronbach Alpha >0,600.

Uji asumsi klasik perlu dilakukan sebelum analisis linier berganda agar pengambilan keputusan mendekati keadaan yang sebenarnya yaitu data terdistribusikan secara normal, tidak mengandung multikolinearitas, dan tidak terjadi heteroskedastisitas (Nasution, dkk., 2019). Adapun uji asumsi klasik yang dilakukan pada penelitian ini adalah berupa uji normalitas, uji multikolinearitas, dan uji heteroskedastisitas.

Uji normalitas dilakukan untuk mengetahui apakah data dari variabel dependen dan variabel independent yang diperoleh berasal dari data yang berdistribusi secara normal atau tidak (Kasmadi dan Sunariah, 2016). Uji normalitas pada penelitian ini menggunakan uji Kolmogorov-Smirnov dengan bantuan program SPSS. Kriteria pengujian normalitas yang digunakan, yaitu apabila nilai $p$ valueSig $>0.05$, maka diterima yang berarti data berdistribusi normal.

Uji multikolinieritas bertujuan untuk mengetahui ada tidaknya hubungan antara variabel bebas yang satu dengan variabel yang lainnya. Ghozali (2016) mengungkapkan bahwa dalam regresi yang baik, disyaratkan tidak terjadi multikolinieritas di antara variabel 
bebas. Untuk mendeteksi adanya multikolinearitas dapat dilihat dari nilai Variance Inflation Factor (VIF) dan nilai Tolerance. Tolerance mengukur variabilitas variabel bebas yang terpilih yang tidak dapat dijelaskan oleh variabel lainnya. Aturan Variance Inflation Factor (VIF) dan tolerance menyatakan apabila VIF melebihi angka 10 atau tolerance kurang dari 0.10 maka dinyatakan terjadi gejala multikolinearitas. Sebaliknya apabila nilai VIF kurang dari 10 atau tolerance lebih dari 0.10 maka dinyatakan tidak terjadi gejala multikolinearitas.

Uji heterokedastisitas dilakukan dengan berdasar pada teori Ghozali (2016) yang menyatakan bahwa uji heterokesdastisitas bertujuan untuk menguji apakah dalam model regresi terjadi ketidaksamaan variance dari residual satu pengamatan ke pengamatan yang lain. Adapun hal yang harus dipenuhi dalam pengujian ini adalah tidak adanya masalah heterokedasitisitas. Untuk mendeteksi adanya heterokedastisitas dilakukan Uji Glejser dengan bantuan program SPSS. Jika nilai signifikansi $>0.05$ maka tidak terjadi heteroskedastisitas pada model regresi, begitu pun sebaliknya.

Sugiyono (2014) menyatakan teknik regresi berganda adalah teknik statistik guna melihat keterkaitan hubungan antara variabel yang digunakan dalam penelitian, yaitu variabel terikat dengan variabel bebas yang telah ditetapkan. Program SPSS digunakan sebagi alat analisis data untuk meregresikan model yang telah dirumuskan.

Sugiyono (2014) menyatakan bahwa uji determinasi adalah uji yang digunakan untuk mengetahui besaran dalam persen pengaruh variabel independen secara keseluruhan terhadap variabel dependen. Nilai koefisien determinasi adalah 0 (nol) atau 1 (satu). Nilai Adjusted $R$ Square yang kecil berarti kemampuan variabel-variabel independen dalam menjelaskan variasi variabel dependen sangat terbatas. Nilai yang mendekati 1 (satu) berarti variabelvariabel independen memberikan hampir semua informasi yang dibutuhkan untuk memprediksi variasi variabel dependen (Ghozali, 2016).

Penggunaan uji t dilakukan untuk menguji signifikansi hubungan antara variabel $\mathrm{X}$ dan Variabel Y secara parsial atau dapat dikatakan uji t pada dasarnya menunjukkan seberapa jauh satu variabel independen secara individual dalam menerangkan variasi-variasi dependen (Ghozali, 2011). Pengujian ini dilakukan dengan menggunakan significance level: 0,05 $(\alpha=5 \%)$ dimana ika nilai probabilitas signifikansi $\mathrm{t}>0,05$, maka $\mathrm{H}_{0}$ diterima dan menolak $\mathrm{H}_{1}$ (koefisien regresi tidak signifikan). Ini berarti bahwa secara parsial variabel independen tersebut tidak mempunyai pengaruh yang signifikan terhadap variabel dependen begitu pula sebaliknya

Uji Moderated Regression Analysis (MRA) adalah pengujian khusus yang dilakukan pada regresi berganda linear dimana dalam persamaan regresinya mengandung unsur interaksi (perkalian dua atau lebih variabel independen).

\section{Hasil dan Pembahasan}

Hasil kuesioner yang disebarkan kepada 100 responden menunjukkan bahwa mayoritas responden, sebesar 54\% memiliki pekerjaan Lainnya diluar PNS, Wirausaha, Swasta, Pedagang dan Petani. Kemudian, pekerjaan yang menempati urutan terbanyak kedua adalah Swasta, yang diikuti oleh Wirausaha, Pedagang, Petani dan PNS secara berurutan. Dalam hal penghasilan, mayoritas responden mengaku memiliki penghasilan kurang dariRp. 1.000 .000 dengan persentase sebanyak $40 \%$ responden. Pada peringkat kedua, sebanyak $29 \%$ responden memiliki penghasilan sebesar 1 juta - 2 juta. Selanjutnya, $14 \%$ responden memiliki penghasilan sebanyak 2 juta - 3 juta, 7\% responden memiliki penghasilan sebanyak 5 juta, dan masing-masing 5\% responden memiliki penghasilan sebanyak 3 juta - 4 juta dan 4 juta 5 juta.

Kemudian, hasil analisis statistik deskriptif menunjukkan bahwa variabel kepatuhan wajib pajak kendaraan bermotor yang berasal dari 100 responden memiliki nilai minimum sebesar 20 dengan nilai maksimum sebesar 50. Diketahui nilai rata-rata variabel kepatuhan 
wajib pajak kendaraan bermotor tersebut sebesar 40,55 sedangkan nilai standar deviasi nya adalah 4,328 yang artinya adalah nilai rata-rata lebih besar dari nilai standar deviasi menunjukkan bahwa kecilnya sebaran data, sehingga data pada variabel kepatuhan wajib pajak kendaraan bermotor (Y) dapat dikatakan baik karena tidak adanya kesenjangan yang cukup besar dari kepatuhan wajib pajak kendaraan bermotor (Y) terendah dan tertinggi. Dengan demikian, dapat dikatakan bahwa penyimpangan data yang terjadi rendah dan penyebaran nilainya merata.

Melalui uji validitas dan reliabilitas ditemukan bahwasemua pernyataan dalam kuesioner valid dan semua jawaban responden sudah konsisten dalam mengukur variabel sanksi pajak kendaraan bermotor (X1), tingkat penghasilan wajib pajak orang pribadi (X2) dan kepatuhan wajib pajak kendaraan bermotor (Y) dalam penelitian ini. Data juga terdistribusikan secara normal, tidak mengandung multikolinearitas, dan tidak terjadi heteroskedastisitas.

Regresi linear berganda yang dilakukan untuk pengujian hipotesis menunjukkan kostanta sebesar 26,497 yang berarti bahwa jika semua variabel independen nilainya adalah 0 maka kepatuhan wajib pajak nilainya sebesar 26,497. Kemudian, koefisien regresi variabel Sanksi Pajak Kendaraan Bermotor (X1) adalah 0,422 artinya jika variabel sanksi pajak kendaraan bermotor naik sebesar 1 maka akan menaikkan kepatuhan wajib pajak kendaraan sebesar 0, 422. Selanjutnya, dari hasil uji t didapatkan hasil bahwa nilai koefisien regresi sebesar 0,422 dengan nilai Sig. sebesar 0,000. Oleh karena koefisien regresi variabel sanksi pajak kendaraan bermotor bernilai positif $(0,422)$, jadi Sanksi pajak kendaraan bermotor memiliki efektivitas yang tinggi terhadap kepatuhan Wajib Pajak orang pribadi dalam membayarkan Pajak Kendaraan Bermotor atau dengan kata lain H1 diterima.

Hasil uji Koefisien Determinasi (Adjust $R^{2}$ ) juga menunjukkan efektivitas yang baik dari sanksi pajak dengan menghasilkan nilai adjusted Rsquare sebesar 0,124. Hal ini menunjukkan bahwa kontribusi variabel sanksi pajak kendaraan bermotor menjelaskan variabel kepatuhan sebesar 12,4\% sedangkan sisanya 87,6\% dijelaskan oleh variabel lain diluar variabel yang digunakan. Namun demikian, pada uji Moderated Regression Analysis (MRA) ditemukan hasil bahwa variabel sanksi pajak kendaraan bermotor memberikan nilai koefisien parameter sebesar 0,488 dengan tingkat signifikansi $0,002(<0,05)$ terhadap kepatuhan wajib pajak kendaraan bermotor. Variabel moderat1 memberikan nilai koefisien parameter sebesar-0,003 dengan tingkat signifikansi sebesar $0,530(>0,05)$. Variabel moderat1 yang merupakan interaksi antara sanksi pajak kendaraan bermotor dengan tingkat penghasilan wajib pajak pribadi yang memoderasi hubungan antara sanksi pajak kendaraan bermotor terhadap kepatuhan wajib pajak kendaraan bermotor memberikan makna variabel tingkat penghasilan wajib pajak pribadi tidak dapat menengahi pengaruh antara sanksi pajak kendaraan bermotor terhadap kepatuhan wajib pajak kendaraan bermotor atau kesimpulannya tidak signifikan, sehingga dapat disimpulkan bahwa variabel tingkat penghasilan wajib pajak pribadi bukan merupakan variabel moderating.

Berdasarkan pemaparan hasil penelitian di atas, dapat dilihat bahwa sanksi pajak kendaraan bermotor memiliki efektivitas yang tinggi terhadap kepatuhan Wajib Pajak orang pribadi dalam membayarkan Pajak Kendaraan Bermotor atau dengan kata lain H1 diterima, yang berarti sanksi pajak kendaraan bermotor memiliki pengaruh dan efektivitas terhadap kepatuhan wajib pajak orang pribadi dalam membayarkan kewajiban PKBnya. Kemudian, dalam uji koefisien determinasi yang dilakukan untuk mengetahui besar dampak variabel independen sanksi pajak kendaraan bermotor terhadap variabel dependen kepatuhan wajib pajak, diperoleh hasil bahwa koefisien determinasi yang ditunjukkan oleh nilai adjusted Rsquare adalah sebesar 0,124. Hal ini menunjukkan bahwa kontribusi variabel sanksi pajak kendaraan bermotor menjelaskan variabel kepatuhan sebesar $12,4 \%$ sedangkan sisanya 
$87,6 \%$ dijelaskan oleh variabel lain diluar variabel yang digunakan. Hal ini menunjukkan bahwa peran dan keberadaan sanksi pajak sebagai upaya preventif dalam menggalakkan kepatuhan wajib pajak masih tergolong efektif dalam mempengaruhi keputusan wajib pajak dalam membayarkan kewajibannya.

Pada item 1-8 yang membahas mengenai sanksi pajak dalam kuesioner penelitian, responden memberikan rerata skala di atas 4 yang menunjukkan bahwa mereka setuju dengan beberapa pernyataan mengenai sanksi pajak kendaraan bermotor. Responden menyatakan setuju bahwa mereka mengetahui keberadaan sanksi bila terlambat membayar PKB, mengetahui fungsi sanksi pajak, menyadari kepatuhan membayar pajak karena tidak ingin dikenakan sanksi, menyatakan keberadaan sanksi sebagai hal yang wajar, mendukung penegakan sanksi pajak, menganggap wajar besaran sanksi PKB, menyatakan sanksi membuat jera dan menyatakan bahwa sanksi pajak mendorong responden untuk membayarkan PKB.

Dengan demikian, dapat dilihat bahwa sanksi pajak memberikan efektivitas yang cukup terhadap kepatuhan wajib pajak kendaraan bermotor di Kabupaten Buleleng. Hal ini sejalan dengan teori yang disampaikan oleh Nugroho (2006) dimana wajib pajak akan memenuhi kewajiban perpajakannya apabila merasa sanksi yang diterapkan dapat memberatkan dirinya. Besaran sanksi yang berupa denda sebesar $25 \%$ per tahunnya yang tetap dikenakan meski hanya terlambat satu hari, telah membuat responden merasa lebih terpacu untuk patuh dalam membayarkan pajak. Selain itu, hasil penelitian ini juga sejalan dengan penelitian sebelumnya yang dilakukan oleh Ummah (2015), Dewi, dkk., (2017), Silalahi (2017) dan Widyana dan Putra (2009).

Uji Moderated Regression Analysis (MRA) yang dilakukan terhadap ketiga variabel dalam penelitian ini menunjukkan bahwa variabel moderat1 sebagai tingkat penghasilan wajib pajak memberikan nilai koefisien parameter sebesar -0,003 dengan tingkat signifikansi sebesar 0,530 (>0,05). Variabel moderat1 yang merupakan interaksi antara sanksi pajak kendaraan bermotor dengan tingkat penghasilan wajib pajak pribadi yang memoderasi hubungan antara sanksi pajak kendaraan bermotor terhadap kepatuhan wajib pajak kendaraan bermotor. Dengan demikian, dapat disimpulkan bahwa variabel tingkat penghasilan wajib pajak orang pribadi tidak dapat menengahi pengaruh antara sanksi pajak kendaraan bermotor terhadap kepatuhan wajib pajak kendaraan bermotor atau kesimpulannya tidak signifikan.

Dengan demikian, $\mathrm{H} 2$ yang menyatakan bahwa tingkat penghasilan wajib pajak mempengaruhi secara positif hubungan antara sanksi pajak kendaraan bermotor dengan kepatuhan wajib pajak orang pribadi dalam membayarkan Pajak Kendaraan Bermotor ditolak. Dengan kata lain, dapat disimpulkan bahwa variabel tingkat penghasilan wajib pajak pribadi bukan merupakan variabel pemoderasi untuk variabel sanksi pajak dan kepatuhan wajib pajak.

\section{Simpulan danSaran}

Berdasarkan hasil analisis yang telah dilakukan peneliti pada pembahasan sebelumnya, dapat disimpulkan bahwa (1) sanksi pajak kendaraan bermotor memberikan efektivitas sebesar $12,4 \%$ terhadap kepatuhan wajib pajak sedangkan (2) tingkat penghasilan wajib pajak bukan merupakan variabel pemoderasi yang mempengaruhi hubungan antara sanksi pajak dengan kepatuhan wajib pajak.

Adapun saran yang dapat diberikan dengan merujuk pada hasil serta pembahasan penelitian ditujukan kepada instansi pemerintah terkait dan peneliti topik terkait di masa depan. Berdasarkan hasil penelitian ini, dapat disarankan kepada instansi pemerintah khususnya Kantor Bersama SAMSAT Buleleng untuk melakukan upaya lainnya di luar sanksi pajak guna menggalakkan kesadaran wajib pajak sekaligus meningkatkan kepatuhan wajib pajak dalam membayarkan kewajibannya.Bagi peneliti berikutnya, disarankan untuk 
meneliti variabel lain yang kemungkinan memiliki efektivitas lebih tinggi terhadap kepatuhan wajib pajak di Kantor Bersama SAMSAT Buleleng karena sanksi pajak memiliki 12,4\% efektivitas dan masih ada 87,6\% variabel lainnya yang kemungkinan memiliki efektivitas tinggi.

\section{Daftar Pustaka}

Bloomquist, K. (2003). Tax Evasion, Income Inequality and Opportunity Costs of Compliance. Proceedings. Annual Conference on Taxation and Minutes of the Annual Meeting of the National Tax Association. 96. 10.2307/41954396.

Candiasa, I.M. (2011). Pengujian Instrumen Penelitian Disertai Aplikasi Iteman dan Bigsteps. Singaraja: Undiksha Press.

Dewi, N. M. P., Diatmika, I. P. G., \& Yasa, I. N. P. (2017) Pengaruh Kesadaran Wajib Pajak, Reformasi Administrasi Perpajakan, dan Persepsi Tentang Sanksi Perpajakan Terhadap Penerimaan Pajak Kendaraan Bermotor (Studi Empiris Pada Kantor Bersama Samsat Buleleng). e-Journal S1 Ak Universitas Pendidikan Ganesha. 8(2).

Ghozali, I. (2011). Aplikasi Analisis Multivariate dengan Program SPSS. Semarang: BP Universitas Diponegoro.

Ghozali, I. (2016). Aplikasi Analisis Multivariete dengan Program IBM SPSS 23. Edisi 8. Semarang: Badan Penerbit Universitas Diponegoro.

Kasiram, M. 2008. Metodologi Penelitian. Malang: UIN-Malang Pers.

Kasmadi., \&Sunariah, N. S. (2016) Metode Penelitian Kuantitatif. Bandung: Alfabeta.

Khoiroh, N. (2017). Pengaruh Sanksi, Sosialisasi, dan Pendapatan Wajib Pajak Terhadap Kepatuhan Wajib Pajak Dalam Membayar Pajak Bumi Dan Bangunan Di Desa Gandaria. Universitas Islam Negeri Syarif Hidayatullah.

Mardiastuti, A. (2019, Agustus 5). Pengumuman! Bayar Pajak Kendaraan di Bali Bebas Denda. Diakses dari https://news.detik.com/berita/d-4653170/pengumuman-bayarpajak-kendaraan-di-bali-bebas-denda.

Muliari, N. K., \& Setiawan, P. E. (2011). Pengaruh Persepsi Tentang Sanksi Perpajakan dan Kesadaran Wajib Pajak Pada Kepatuhan Pelaporan Wajib Pajak Orang Pribadi di Kantor Pelayanan Pajak Pratama Denpasar Timur. Jurnal Ilmiah Akuntansi dan Bisnis (JIAB). 6(1).

Nasution, A. E., Putri, L. P., \& Lesmana, M. T. (2019). Analisis Pengaruh Harga, Promosi, Kepercayaan dan Karakteristik Konsumen Terhadap Keputusan Pembelian Konsumen Pada 212 Mart di Kota Medan. Proseding Seminar Nasional Kewirausahaan, 1(1), 2019, hal 194-199. DOI: https://doi.org/10.30596/snk.v1i1.3594.

Nugroho, A. J.(2006). Pengaruh Sikap Wajib Pajak Pada Pelaksanaan Sanksi Denda, Pelayanan Fiskus dan Kesadaran Perpajakan terhadap Kepatuhan Wajib Pajak (Studi Empirir terhadap Wajib Pajak Orang Pribadi di Kota Semarang. Universitas Diponegoro. Semarang.

Nurlaela, L. (2018). Effect of Tax Service Quality and Tax Sanctions Againts Vehicle Taxpayer Compliance at the Samsat Office of Garut District. International Seminar \& Conference on Learning Organization. 6. 310-317.

Peraturan Daerah Provinsi Bali No. 1 Tahun 2011 tentang Pajak Daerah. Diakses pada Mei 
11, 2020 dari https://peraturan.bpk.go.id/Home/Details/17195/perda-prov-bali-no-1tahun-2011.

Riahi, B. A. (2004). Teori Akuntansi. Edisi kelima. Salemba Empat. Jakarta.

Siahaan, M. P. 2004. Utang Pajak Pemenuhan Kewajiban dan Penagihan Pajak dengan Surat Paksa. PT Raja Grafindo Persada. Jakarta.

Silalahi, T. (2017). Analisis Beberapa Faktor yang Mempengaruhi Kepatuhan Wajib Pajak Membayar Pajak Kendaraan Bermotor di Kantor Bersama Samsat Buleleng. Universitas Udayana, Denpasar, Bali.

Setiawan, N. 2007. Penentuan Ukuran Sampel Memakai Rumus Slovin dan Tabel KrejcieMorgan: Telaah Konsep dan Aplikasinya. Universitas Padjajaran.

Sugiyono. (2014). Metode Penelitian Kuantitatif, Kualitatif, dan R\&D. Bandung: Alfabeta.

Torgler, B., 2003, Tax Morale : Theory and Analysis of Tax Compliance, Unpublished doctoral dissertion, University of Zurich, Switzerland.

Ummah, Muslikhatul. (2015). Pengaruh Kesadaran Wajib Pajak, SanksiPajak, Pengetahuan Perpajakan Dan Pelayanan Fiskus TerhadapKepatuhan Wajib Pajak Kendaraan Bermotor Di Kabupaten Semarang.Fakultas Ekonomi Universitas Dian Nuswantoro.

Undang-Undang Republik Indonesia Nomor 32 Tahun 2004 tentang Pemerintahan Daerah. Diakses pada Mei 11, 2020 dari http://www.dpr.go.id/dokjdih/document/uu/33.pdf.

Undang-Undang Republik Indonesia Nomor 33 Tahun 2004 tentang Perimbangan Keuangan antara Pemerintah Pusat dengan Pemerintahan Daerah. Diakses pada Mei 11, 2020 dari https://peraturan.bpk.go.id/Home/Details/40770/uu-no-33-tahun-2004.

Undang-Undang Republik Indonesia Nomor 28 Tahun 2009 tentang Pajak Daerah Dan Retribusi. Diakses pada Mei 11, 2020 dari http://www.djpk.kemenkeu.go.id/attach/postno-28-tahun-2009-tentang-pajak-daerah-dan-retribusi-daerah/UU-427-973-

UU_28_Tahun_2009_Ttg_PDRD.pdf.

Widnyani, I. A. D., \& Suardana, K. A. (2016). Pengaruh Sosialisasi, Sanksi, dan Persepsi Akuntabilitas terhadap Kepatuhan Wajib Pajak dalam Membayar Pajak Kendaraan Bermotor. E-Jurnal Akuntansi Universitas Udayana. 16(3), 2176-2203.

Widyana, D. P. G., dan Putra, I. N. W. A. (2019). Pengaruh Kesadaraan Wajib Pajak, Pelayanan Fiskus, dan Sanksi Pajak Terhadap Kepatuhan Wajib Pajak Kendaraan Bermotor. e-Jurnal Akuntansi Universitas Udayana. 30(1). 39-55.

Wijaya, Pramana. (2020, Januari 31). Realisasi PKB Bali Capai Rp. 1,5 Triliun, Ini UPT Penyumbang Terbesar. Diakses dari https://www.balipost.com/news/2020/01/31/101765/Realisasi-PKB-Bali-CapaiRp...html.

Winerungan, L. O. 2013. "Sosialisasi Perpajakan, Pelayanan Fiskus dan Sanksi Perpajakan terhadap Kepatuhan WPOP di KPP Manado dan KPP Bitung”. Jurnal EMBA. Vol.1, No.3, 960-970. 